\title{
ELŻBIETA ZEBEK
}

University of Warmia and Mazury in Olsztyn, Poland

elzbieta.zebek@uwm.edu.pl

ORCID ID: 0000-0002-8637-8391

LEDA ZILINSKIENE்

Mykolas Romeris University in Vilnius, Lithuania

leda.zilinskiene@gmail.com

ORCID ID: 0000-0001-6297-4247

\section{WASTE MANAGEMENT AND HUMAN RIGHTS \\ TO THE ENVIRONMENT IN POLISH AND LITHUANIAN LEGAL SOLUTIONS}

\begin{abstract}
Basic human rights are set out in the Universal Declaration of Human Rights. Moreover, human rights to the environment were identified with 3rd generation human rights as the principles of solidarity and subsidiarity. These rights may be disturbed through pollution of the environment causing by improper waste management... Therefore, it is important to comply with the various principles of waste management specified in the Directive 2008/98/EC, which provisions were implemented into the legislation of Poland and Lithuania. The purpose of this article is indicate the legal principles of waste management and human rights to the environment for example of these countries. In Poland, waste management should be carried out with the protection of human health and life, in particular, it must not pose a threat to environmental elements and effects on cultural and natural areas. Similarly, there are protected the same resources in Lithuania with paying attention to not exceeding the normative standards.

Therefore, principles of environmental law and waste management plays a crucial role in safeguarding human right to environment due to their needs.
\end{abstract}

KEYWORDS: environmental law, human rights, principles of waste management, EU countries 


\section{INTRODUCTION}

Man is an element of the environment and cannot exist without its resources of adequate quantity and quality. It is very important for ecological safety reasons. The development of civilization has significantly contributed to the degradation and pollution of such elements of the environment as water, air, soil, and natural habitats, as a result of which they have become limited to society, especially in poorer and underdeveloped countries. Hence, along with the need to protect these resources, there was a need to protect human rights to access them.

Human rights to the environment and at the same time the need to protect its resources are reflected in the principle of sustainable development, first defined at the Rio de Janeiro conference in 1992. According to the Declaration, sustainable development is based on three pillars essential for the security of the world and the development of civilization: international human rights law, international environmental law and international economic law ${ }^{1}$. This act also established human rights to the environment, which, according to the classification of human rights in the Universal Declaration of Human Rights ${ }^{2}$, belong to social rights included in the third generation of human rights.

One of the activities of human anthropogenic activity is waste management, which is quite burdensome for the environment and humans. Illegal waste management causes contamination of water, air and soil, i.e. deterioration of the quality of these environmental resources, which at the same time limits their use for various purposes, i.e. living and economic. Therefore, the deterioration of the quality of these resources to some extent restricts human rights to a clean environment, that is, of appropriate quality that meets environmental standards. In order to reduce the negative impact of waste management on the environment and humans, it is important to comply with the legal principles of waste management and the hierarchy of waste management methods in the

1 M. Roliński, Z problematyki zasad ochrony środowiska, „Studia Iuridica Lublinensia” 2014, no. 21 , p. $145-155$.

2 Universal Declaration of Human Rights (UN General Assembly resolution 217 A (III) adopted and proclaimed on 10 December 1948). 
EU specified in the Directive 2008/98/EC of the European Parliament and of the Council of 19 November 2008 on waste and repealing certain Directives ${ }^{3}$.

The provisions of this Directive have been implemented by the Member States, including Poland and Lithuania.

The purpose of this article is indicate the legal principles of waste management and human rights to the environment for example of Poland and Lithuania. It was formulated the following research questions: 1) What is the relations between human rights to the environment and legal principles of waste management? and 2) What are legal regulations of waste management in Poland and Lithuania? The article uses the legal-dogmatic and comparative method consisting in the analysis of legal regulations in the field of human rights to the environment, the principles of waste management in Poland and Lithuania, and the literature on the subject.

\section{HUMAN RIGHTS TO THE ENVIRONMENT AND SUSTAINABLE DEVELOPMENT}

Basic human rights are set out in the Universal Declaration of Human Rights. These rights are divided into three groups: 1st generation human rights - personal and political rights (freedom rights and the principle of freedom), 2nd generation human rights - economic, social and cultural rights (social rights and the principle of equality) and 3rd generation human rights - solidarity rights (the principles of solidarity and subsidiarity) ${ }^{4}$. According to the above rights, human rights to the environment were identified with a catalog of political and social rights. Moreover, in the Charter of Fundamental Rights of the European Union ${ }^{5}$ human right to the environment is included in the

OJ L 312, 22.11.2008, p. 3-30.

4 Universal Declaration of Human Rights of 1948; see more: B. Banaszak, Ogólne wiadomości o prawach człowieka, [in:] B. Banaszak, A. Preisner (eds.), Prawa i wolności obywatelskie w Konstytucji RP, C.H. Beck, Warsaw 2002, p. 29; M. Nowak, Trzy generacje praw człowieka. Ich znaczenie w świetle przesłanek ideowych i historycznych oraz $w$ świetle ich genezy, [in:] Banaszak (ed.), Prawa człowieka. Geneza, koncepcje, ochrona, Wrocław University Press, Wrocław 1993, p. 105.

5 The Charter of Fundamental Rights of the European Union, signed in 7 December 2000 in Nicea, with changes 12 December 2007 in the Lisbon Treaty has entered into force 1 December 2009. 
third generation of solidarity law. Pursuant to Article 28 of the Universal Declaration of Human Rights, which justifies the adherence of the above right to the environment, to a healthy and sustainable environment, and to the third generation law (solidarity law): "Everyone is entitled to a social and international order in which the rights and freedoms may be fully implemented in this Declaration". The right to the environment consists of a group of human rights regarding the environment, such as: a) the right to live in an environment that ensures mental and physical health, b) the right to information about the environment, $\mathrm{c}$ ) the right to participate in decision-making about the environment, and d) the right to use the value of the environment (no economic character) ${ }^{7}$.

Human rights to the environment were also set out in two leading documents establishing the principles of environmental law: the Stockholm Declaration of 1972 and the Riod de Janeiro Declaration of $1992^{8}$. The Stockholm Declaration formulated a direct link between human rights and the environment. The first principle states that: "Man has the fundamental right to the freedom of equality and adequate living conditions in an environment of a quality that allows him to live in dignity and prosperity. He is also responsible for protecting and improving the environment for present and future generations" ${ }^{\prime \prime . . . M o r e o v e r, ~ i n ~ t h e ~ R i o ~ d e ~ J a n e i r o ~ D e c l a r a t i o n, ~ h u m a n ~ r i g h t s ~ t o ~ t h e ~}$ environment were taken into account in the definition of the most important rule of environmental protection law - the principle of sustainable development, linking human rights with environmental and economic rights, with is included in: „Man has the right to freedom, equality and appropriate living conditions in the environment, and economic development should be carried out in accordance with the principle of sustainable development". The reference to

6 M.M. Kenig-Witkowska, Prawo środowiska w prawie międzynarodowym, „Państwo i Prawo” 2000, no. 8, p. 28; M. Piechowiak, Filozofia praw człowieka w świetle ich międzynarodowej ochrony, Lublin 1999, p. 65.

7 T. Bojar-Fijałkowski, Elementy zarządzania jakościa izarządzania środowiskowego wspomagajace nowe zarzadzanie publicznej w administracji, [in:] E. Jasiuk, G. P. Maj, K. Sikora, S. Wrzosek (eds.), Pomiędzy zarządzaniem publicznym a ogólną teorią administracji, Radom 2013, pp. 127-144.

8 M. Sitek, B. Sitek, (2021). The Necessity for the Implementation of a Global Environmental Policy for the Needs and Conditions and Local Communities. A Comparative Study. Regional Formation and Development Studies, 34(2), 2021, p. 192. doi:10.15181/rfds.v34i2.2255

9 Resolution of the Stockholm Conference of June 14, 1972 regarding the natural environment of man (UN Conference). 
the principle of sustainable development is reflected in the three principles of the declaration: 1) Principle 3 - The right to development must be fulfilled so as to equitably meet developmental and environmental needs of present and future generations; 2) Principle 4 - In order to achieve sustainable development, environmental protection shall constitute an integral part of the development process and cannot be considered in isolation from it.; and Principle 8 - To achieve sustainable development and a higher quality of life for all people, States should reduce and eliminate unsustainable patterns of production and consumption and promote appropriate demographic policies. The human right to the environment were included in the legislations of European countries, acting in a constitutional catalog of rights.

\section{Principles of WASte management in EU}

The basic legal act in the European Union that defines the principles of waste management is the Waste Framework Directive 2008/98/EC. Directive lays down measures to protect the environment and human health by preventing or reducing the adverse impacts of the generation and management of waste and by reducing overall impacts of resource use and improving the efficiency of such use. The waste management is very widely determined by the Directive and included the collection, transport, recovery and disposal of waste, including the supervision of such operations and the after-care of disposal sites, and including actions taken as a dealer or broker (Article 3(9)).

Article 4 of Waste Framework Directive states that Member States shall take into account the general environmental protection principles of precaution and sustainability, technical feasibility and economic viability, protection of resources as well as the overall environmental, human health, economic and social impacts, in accordance with Articles 1 and 13. The principle of sustainability as general environmental principal gains a special recognition in the area of waste regulation.

Under Article 13 Member States shall take the necessary measures to ensure that waste management is carried out without endangering human health, without harming the environment and, in particular: 1) without risk to water, air, soil, plants or animals; 2) without causing a nuisance through noise or 
odours; and 3) without adversely affecting the countryside or places of special interest. The waste management should be carried out according to the waste hierarchy. The waste hierarchy generally lays down a priority order of what constitutes the best overall environmental option in waste legislation and policy, while departing from such hierarchy may be necessary for specific waste streams when justified for reasons of, inter alia, technical feasibility, economic viability and environmental protection. Under Article 4 the following waste hierarchy shall apply as a priority order in waste prevention and management legislation and policy: (a) prevention; (b) preparing for re-use; (c) recycling; (d) other recovery, e. g. energy recovery; and (e) disposal. This hierarchy sets the order of priority actions for applying the best all-round solution for the environment in legislation and economic policy waste. This scheme is the basic guideline for Member States when designing waste management systems, in which the use of separated waste as a result of recycling should be encouraged, and the storage or incineration processes of such waste should be treated as a last resort.

The most important principles of waste management set out in Article 16 of this Directive are the principle of self-sufficiency and proximity. This involves taking appropriate measures when necessary or desirable, in order to establish an integrated and sufficient network of disposal facilities waste and installations for the recovery of mixed municipal waste collected from households, taking into account the best available techniques. Such a network as well it should enable the neutralized waste or the recovery of waste in one of the closest located appropriate installations, by the most appropriate methods and technologies, in order to ensure a high level of protection for the environment and public health ${ }^{10}$.

An important legal instrument established by the Directive is waste management plans. The waste management plans shall set out an analysis of the current waste management situation in the geographical entity concerned, as well as the measures to be taken to improve environmentally sound preparing

10 See more: M. Jabłoński, Administracyjne podstawy kompetencji Unii Europejskiej i państw członkowskich $w$ zakresie problematyki odpadów. W stronę spójnej polityki $w$ gospodarce odpadami, „Ochrona i Środowisko” 2011, no. 6, pp. 24-33; P. Korzeniowski, Model prawny systemu gospodarki odpadami. Studium administracyjnoprawne, UŁ Press, Łódź 2014; E. Zębek, Waste management in legal and environmental terms, KPP Monograph, UWM Press, Olsztyn 2018... 
for re-use, recycling, recovery and disposal of waste and an evaluation of how the plan will support the implementation of the objectives and provisions of this Directive (Article 28). The waste management plans shall contain, as appropriate and taking into account the geographical level and coverage of the planning area, at least the following: (a) the type, quantity and source of waste generated within the territory, the waste likely to be shipped from or to the national territory, and an evaluation of the development of waste streams in the future; (b) existing waste collection schemes and major disposal and recovery installations, including any special arrangements for waste oils, hazardous waste or waste streams addressed by specific Community legislation; (c) an assessment of the need for new collection schemes, the closure of existing waste installations, additional waste installation infrastructure, and, if necessary, the investments related thereto; (d) sufficient information on the location criteria for site identification and on the capacity of future disposal or major recovery installations, if necessary; (e) general waste management policies, including planned waste management technologies and methods, or policies for waste posing specific management problems. These provisions have been implemented into the laws of Poland and Lithuania, especially in the waste laws.

\section{HUMAN RIGHTS TO THE ENVIRONMENT AND WASTE management in Poland}

In the Polish legislation, the human rights to the environment are determined in the Polish Constitution of 2 April, 1997 ${ }^{11}$. Under Article 5 The Republic of Poland guards the independence and inviolability of its territory, ensures the freedoms and rights of human and citizens as well as the security of citizens, guards the national heritage and ensures environmental protection, guided by the principle of sustainable development. The environment is a value that is not only subject to authorization, but is also an extremely important public value. The right of citizens to enjoy the environment is one of the fundamental rights of the citizens of that country. More importantly, the

11 Law Journal of 1997, No. 78, item 483 as amended. 
Constitution does not directly mention the right to a clean environment, but lists derivative rights, such as: the right to health protection by counteracting the effects of environmental degradation (Article 68), the right to support activities aimed at protection and improvement of the environment, as well as the right to access information on the protection and state of the environment (Article 74). According to Article 74 public authorities are obliged to pursue a policy ensuring ecological safety for contemporary and future generations. Ecological security is defined as security by each state of life and the health of its citizens, and of its natural resources from harm, and threats from environmental pollution, icluding caused by waste management. It is about threats to preserve the natural environment of man at the level necessary for the survival and development of mankind. Therefore, referring to the above legal aspects regarding the right to environmental protection, to live in a safe, healthy, appropriate environment, it seems fully justified to say that Poland guarantees the right to a clean environment in a fairly wide scope ${ }^{12}$.

Principles of waste management are regulated by the Waste Act of $2012^{13}$ in the Section II General principles of waste management, Chapter 1 Protection of human life and health and the environment. Under Article 16 the waste management should be conducted in a manner ensuring protection of human life and health and the environment, in particular waste management cannot: 1) cause threats to water, air, soil, plants or animals; 2) cause nuisance through noise or smell; and 3) cause adverse effects on rural areas or places of special importance, including cultural and natural. The waste management should be carried in regard the hierarchy of ways of dealing with waste. The following hierarchy of procedures is introduced with waste: 1) waste prevention; 2) preparing for re-use (mechanical and biological methods of mixed municipal waste treatment to waste preparation for recovery); 3 ) recycling (material and organic - composting); 4) other recovery processes; and 5) disposal (thermal transformation of waste and landfilling) (Article 17). Similar to the Directive 2008/98/EU the most important principles in the waste management are the principle of self-sufficiency and proximity. Under Article 9 of the Waste Act,

12 J. Ciechanowicz-McLean (ed.), Leksykon ochrony środowiska, C.H. Beck, Warsaw 2009, p. 15; A. Surówka, Bezpieczeństwo ekologiczne a gospodarowanie odpadami w świetle prawa konstytucyjnego, „Przegląd Prawa Konstytucyjnego” 2012, no. 4, pp. 151-167.

13 Consolided text of 2021 , item 779. 
the proximity principle is based on the recovery or disposal of waste at the place where it is generated. This provision implies a ban on unjustified shipments of waste applicable to all stages of waste management. According to this principle, waste, taking into account the hierarchy of waste handling methods, should be treated first processing at the place of their origin (Article 20). ${ }^{14}$

In the literature on the subject, it is believed that the principles of waste management fulfill two main functions: (1) the function of organizing the waste management law system and (2) the function of environmental protection. Thus, the principles of waste management they pursue the following objectives: (a) reducing waste as much as possible during all economic activity and human existence, (b) immediate incorporation of post-production residues into production, (c) recovery of raw materials from collected waste, (d) the use of waste treatment processes; and (e) the storage of waste in an orderly manner with minimal environmental impact. These principles are determined by the correct handling of waste, both theoretical and practical aspects ${ }^{15}$. In addition, the important instrument of waste management is waste management plans. Under Article 34 these plans are developed in order to achieve the goals assumed in the environmental protection policy, decoupling the trend of increasing the amount of waste generated and its impact on environment from the country's economic growth tendency, the implementation of the hierarchy of ways waste management and the principles of self-sufficiency and proximity, and establishing and maintaining an integrated and sufficient network of installations in the country waste management that meets the requirements of environmental protection.

14 M. Górski, Zasada bliskości w przepisach o gospodarowaniu odpadami, „Przegląd Komunalny” 2010, no. 1(22), pp. 28-29.

15 K. Szuma, Wybrane problemy gospodarowania odpadami w świetle założeń Deklaracji RIO+20 „Przyszłość, jaka chcemy mieć”, „Białostockie Studia Prawnicze” 2013, no. 14, pp. 113-125. 


\section{HUMAN RIGHTS TO THE ENVIRONMENT AND WASTE MANAGEMENT IN LITHUANIA}

The Constitution of the Republic of Lithuania sets a legal basis for protection of the environment though it does not include a specific right to a healthy environment. It's stated in Article 53 of the Constitution of the Republic of Lithuania that "The State and each person must protect the environment from harmful influences". Article 54 stipulates that "The State shall take care of the protection of the natural environment, wildlife and plants, individual objects of nature and areas of particular value and shall supervise a sustainable use of natural resources, their restoration and increase. The destruction of land and the underground, the pollution of water and air, radioactive impact on the environment as well as depletion of wildlife and plants shall be prohibited by law.". It is recognized in the constitutional doctrine of Lithuania that "one of the objectives of the activities of the state, i. e. to ensure people's rights to a healthy and clean environment" 16.

The state must guarantee everyone the implementation of natural rights, including the right to safe environment ${ }^{17}$.

Some authors argue that provisions of the Constitution indirectly regulate relations between human rights and environmental and does not establish the human right to a healthy environment ${ }^{18}$. In some classifications civil and political rights are considered as individual rights, which are guaranteed judicial protection, thought social, economic and cultural rights are understood as programmatic and consistently implemented rights. In the decisions of constitutional courts these rights are increasingly recognised as individual rights $^{19}$. Despite general trend in recognition of right to a healthy and clean

16 The Constitutional Court of the Republic of Lithuania 9 May 2014, ruling on the compliance of item 166.4 of The State strategic waste management plan, as approved by the resolution of the Government of the Republic of Lithuania (No. 519) "On the approval of the State strategic waste management plan" of 12 April 2002, with the Constitution of the Republic of Lithuania, https://www.lrkt.lt/en/court-acts/search/170/ta856/content.

17 E. Monkevičius et al., Aplinkosaugos teisè, Justitia, Vilnius 2011, p. 34.

18 G. Gaidys, Żmogaus teisès į sveika aplinką statuso identifikavimo problemos, „Socialinių mokslų studijos Social Sciences Studies" 2009, no. 1(1), p. 60, https://www3.mruni.eu/ojs/ societal-studies/article/download/1440/1380.

19 T. Birmontienè, Żmogaus teisés ir laisves. In Lietuvos konstitucinè teisè, VI Registrų centras, Vilnius 2017, pp. 275-276, https://www.registrucentras.lt/bylos/dokumentai/literatura/ Lietuvos\%20konstitucin\%C4\%97 \%20teis \%C4\%97.pdf. 
environment, the conditions for recognition of this right and it's limits still has to be tested in Lithuanian courts.

Waste management is not mentioned in the Constitution of the Republic of Lithuania, but constitutional doctrine recognizes negative impact of poor waste management. The Constitutional Court in the ruling of 9 May $2014^{20}$ noted that "when regulating the organisation of waste management as one of the types of economic activity, the legislature must take account of the fact that improperly managed waste endangers the environment, human and public health, and it must also pay heed to the imperative of using natural resources in a rational manner.". Waste management also fall within a notion of freedom of individual economic activity and economic initiative that is consolidated in Paragraph 1 of Article 46 of the Constitution.

The Republic of Lithuania law on waste management of $1998^{21}$ (Law on waste management) establishes basic requirements for the prevention, record keeping, collection, transport, sorting, storage and treatment of waste with a view to preventing its negative effects on the environment and human health. It also includes principles of organisation and planning of waste management systems. The Law on waste management is the main legal act transposing the requirements of the Waste framework directive 2008/98/EB (WFD) into national law.

Following the wording of 13 article of WFD, Article 4 of the Law on waste management stipulates that waste management must be carried out: 1) without exceeding the normative standards of environmental protection specified by legal acts for water, air or soil pollution and without adversely affecting public health, plants or animals; 2) without exceeding the noise or odour normative standards specified by legal acts; 3 ) without adversely affecting the landscape or places of environmental, natural and/or cultural importance.

Under Article 3, in the area of waste prevention and management, waste hierarchy as the following priority is applied: 1) prevention; 2) preparing

20 The Constitutional Court of the Republic of Lithuania 9 May 2014, ruling on the compliance of item 166.4 of The State strategic waste management plan, as approved by the resolution of the Government of the Republic of Lithuania (No. 519) "On the approval of the State strategic waste management plan" of 12 April 2002, with the Constitution of the Republic of Lithuania, p. 8.1, https://www.lrkt.lt/en/court-acts/search/170/ta856/content.

21 The Republic of Lithuania law on waste management, https:/e-seimas.lrs.lt/portal/legalAct/ lt/TAD/ eccff681441b11e68f45bcf65e0a17ee?jfwid=q8i88lai9. 
for re-use upon prior separation of products or their components which are unsuitable for re-use; 3 ) recycling upon prior separation of wastes which are unsuitable for recycling; 4) other recovery, e.g. energy recover, upon prior separation of wastes which are unsuitable for recycling or other recovery; 5) disposal upon prior separation of wastes which are suitable for recycling or other recovery. The priority order in waste prevention and management shall take into account the general environmental protection principles of precaution and sustainability, technical feasibility and economic viability, protection of resources as well as the overall environmental, public health, economic and social impacts.

The National Strategic Plan for Waste Management specify tasks of waste management, strategic goals of waste managements and targets to implement them. Regional waste management plans and Waste management plans of municipalities stipulate measures for ensuring the implementation of these tasks. In Lithuania, local governments are responsible for organising municipal waste management and for reaching EU targets regarding recycling and recovery (except some waste stream (packaging, waste electrical and electronic equipment, batteries and accumulators waste, end-of-life vehicles and oils) which are managed by extended producer responsibility.

The legal regulation of Lithuanian waste management complies with the provisions enshrined in the Constitution of the Republic of Lithuania, which oblige the state to ensure people's rights to a healthy and clean environment. Freedom of individual economic activity and economic initiative is constitutionally guaranteed, but the potential negative effects of waste on the environment justify the application of strict requirements for actors of the waste management system which is supplemented by extended producer responsibility. 


\section{Conclusions}

Human rights to life are closely related to environmental rights. It is especially important nowadays with increased anthropopression causing significant environmental pollution. One of the manifestations of such activity is waste management. Based on the above argument on the analysis of international, EU and national regulations, for example in Poland and Lithuania, it can be concluded that waste management is closely related to human rights to the environment. The following has been found:

Human rights to the environment and the need to protect the environment under conditions of sustainable development are constitutionally guaranteed in both countries, although there is no direct indication of waste management.

In Poland, waste management should be carried out with the protection of human health and life, in particular, it must not pose a threat to water, air, soil, plants or animals, nuisance due to noise or smell and adverse effects on cultural and natural areas.

Similarly, in Lithuania, the legislator protects these elements of the environment paying attention to not exceeding the normative standards of environmental protection specified by legal acts, the same applies to the standards of odours and natural and cultural areas...

In summary, principles of environmental law and waste management plays a crucial role in safeguarding human right to environment and only their observance will allow the preservation of environmental resources of appropriate quality and quantity and their protection for human needs. 


\section{REFERENCES}

Banaszak, B. (2002), Ogólne wiadomości o prawach człowieka. [in:] B. Banaszak, A. Preisner (eds.), Prawa i wolności obywatelskie w Konstytucji RP. C.H. Beck. Warsaw.

Birmontienè, T. (2017). Žmogaus teisès ir laisvès. [in:] Lietuvos konstituciné teisé... VIt Registrų centras. Vilnius. https://www.registrucentras.lt/bylos/dokumentai/ literatura/Lietuvos\%20 konstitucin\%C4\%97 \%20teis \%C4\%97.pdf

Bojar-Fijałkowski, T. (2013). Elementy zarządzania jakościa i zarządzania środowiskowego wspomagające nowe zarządzanie publicznej w administracji.[in:] E. Jasiuk, G. P. Maj, K. Sikora, S. Wrzosek (eds.), Pomiędzy zarządzaniem publicznym a ogólna teoria administracji. Radom.

Ciechanowicz-McLean, J. (ed.) (2009). Leksykon ochrony środowiska, C.H. Beck. Warsaw.

Directive 2008/98/EC of the European Parliament and of the Council of 19 November 2008 on waste and repealing certain Directives (OJ L 312, 22.11.2008, p. 3-30).

Gaidys, G. (2009). Žmogaus teisés ị sveikg aplinka statuso identifikavimo problemos. Socialinių mokslų studijos Social Sciences Studies.no. 1(1). https://www3.mruni. eu/ojs/societal-studies/article/download/1440/1380.

Górski, M. (2010). Zasada bliskości w przepisach o gospodarowaniu odpadami. Przegląd Komunalny, no. 1(22).

Jabłoński, M. (2011). Administracyjne podstawy kompetencji Unii Europejskiej i państw członkowskich w zakresie problematyki odpadów. W stronę spójnej polityki w gospodarce odpadami. Ochrona i Środowisko, no. 6.

Kenig-Witkowska, M. M. (2000). Prawo środowiska w prawie międzynarodowym. Państwo i Prawo, no. 8.

Korzeniowski, P. (2014). Model prawny systemu gospodarki odpadami. Studium administracyjnoprawne. UŁ Press. Łódź.

Monkevičius, E. et al. (2011). Aplinkosaugos teisé...Justitia. Vilnius.

Nowak, M. (1993). Trzy generacje praw człowieka. Ich znaczenie w świetle przesłanek ideowych i historycznych oraz $w$ świetle ich genezy. [in:] Banaszak (ed.), Prawa człowieka. Geneza, koncepcje, ochrona. Wrocław University Press. Wrocław.

Piechowiak, M. (1999). Filozofia praw człowieka wświetle ich międzynarodowej ochrony. Lublin.

Polish Constitution of 2 April, 1997 (Law Journal of 1997, No. 78, item 483 as amended).

Resolution of the Stockholm Conference of June 14, 1972 regarding the natural environment of man (UN Conference).

Roliński, M. (2014). Z problematyki zasad ochrony środowiska. Studia Iuridica Lublinensia, no. 21.

Surówka, A. (2012). Bezpieczeństwo ekologiczne a gospodarowanie odpadami w świetle prawa konstytucyjnego. Przegląd Prawa Konstytucyjnego, no. 4. 
Szuma, K. (2013)...Wybrane problemy gospodarowania odpadami w świetle założeń Deklaracji RIO+20 „Przyszłość, jaka chcemy mieć”. Białostockie Studia Prawnicze, no. 14.

The Charter of Fundamental Rights of the European Union, signed in 7 December 2000 in Nicea, with changes 12 December 2007 in the Lisbon Treaty has entered into force 1 December 2009.

The Republic of Lithuania law on waste management, https://e-seimas.lrs.lt/portal/ legalAct /lt/TAD/ecccf681441b11e68f45bcf65e0a17ee?jfwid=q8i88lai9.

Universal Declaration of Human Rights (UN General Assembly resolution 217 A (III) adopted and proclaimed on 10 December 1948).

Waste Act of 2012 (consolided text of 2021, item 779).

Zębek, E. (2018). Gospodarka odpadami w ujęciu prawnym i ekologicznym. KPP Monograph. UWM Press. Olsztyn. 